\title{
Investigating the feasibility of short-duration hot water treatments for apple disinfestation
}

\author{
S.P. Redpath, L.E. Jamieson, N.E.M. Page-Weir, M.K.D. Hall, S.R. Olsson, \\ M.J. Griffin, A. Chhagan and A.B. Woolf \\ The New Zealand Institute for Plant \& Food Research Limited, Private Bag 92169, Auckland, \\ 1142, New Zealand \\ Corresponding author: simon.redpath@plantandfood.co.nz
}

\begin{abstract}
The presence of live pests on packed apples is a concern for many of New Zealand's export markets. Greedy and latania scale, onion thrips, apple leafcurling midge (diapausing larvae) and obscure mealybug were subjected to hot water treatments (HWT) of $49.5,51.0$ or $52.5^{\circ} \mathrm{C}$ for either 1,2 or $3 \mathrm{~min}$. Latania, greedy scale and onion thrips were the most susceptible pests to HWT, with either $2-3 \mathrm{~min}$ at $49.5^{\circ} \mathrm{C}$ or $\geq 1 \mathrm{~min}$ at 51.0 or $52.5^{\circ} \mathrm{C}$ achieving $>80 \%$ mortality. HWT of $52.5^{\circ} \mathrm{C}$ for $1-3$ min consistently achieved $>90 \%$ mortality of apple leaf curling midge diapausing larvae. Obscure mealybug was the most tolerant species tested, with mortalities of $60-70 \%$ at 51.0 or $52.5^{\circ} \mathrm{C}$ for 2 or $3 \mathrm{~min}$. A HWT of $51^{\circ} \mathrm{C}$ for $2 \mathrm{~min}$ did not affect quality of 'Royal Gala, 'Fuji' and 'Braeburn' apples. There is potential for short-duration HWTs to achieve high mortalities of a range of insects, while resulting in minimal damage to apple fruit.
\end{abstract}

Keywords heat treatment, greedy scale, latania scale, onion thrips, apple leaf curling midge, obscure mealybug, postharvest, insects, Hemiberlesia rapax and Hemiberlesia lataniae, Thrips tabaci, Dasineura mali, Pseudococcus viburni.

\section{INTRODUCTION}

The presence of pests (i.e. mites, mealybugs, scale, lepidopteran larvae, thrips, apple leafcurling midge, woolly apple aphid) on packed apples is a concern for many export markets such as Asia, Australia and USA. The continuing phase-out of chemicals (e.g. methyl bromide and organophosphates) for pest and decay control has increased commercial interest in non-chemical technologies that might allow greater market access for pipfruit. One such technology is disinfestation of fruit using heat treatment (Mangan \& Hallman 1997; Lurie 1998; Ferguson et al. 2000; Tang et al. 2007; Heather \& Hallman 2008).
Generally hot water treatments (HWTs) are more effective at any given temperature than hot air treatments, because heat transfer in water is faster and, when high water flows are used, heating of fruit is more uniform. Additionally HWTs generally cost less to apply (Waddell et al. 1993) and have the advantage of reducing residues, pathogens and other contaminants (i.e. pollen), as well as washing off dead pests. Short but high temperature HWTs are effective at controlling fungal pathogens and pests on the fruit surface (Fallik 2004; Teruya et al. 2012).

Longer treatments, to heat the whole fruit, are required for internal pests such as codling moth 
and fruit fly larvae (Lurie 1998), but are likely to damage temperate crops such as apples. However, there is evidence that some apple cultivars tolerate HWT of $48-53^{\circ} \mathrm{C}$ for $1-3$ min (Spooner \& Lay-Yee 1994, 1995; Maxin et al. 2012a,b), which may have potential to control external pests.

This study aimed to determine the mortality of a range of pests and the effect on fruit of three apple cultivars ('Royal Gala', 'Fuji' and 'Braeburn') after HWTs of between 49.5 and $52.5^{\circ} \mathrm{C}$ for $1-3 \mathrm{~min}$.

\section{MATERIALS AND METHODS Insects}

Greedy scale (Hemiberlesia rapax) and latania scale insects ( $H$. lataniae) were reared on red-skinned potatoes at $20-23^{\circ} \mathrm{C}, 16: 8 \mathrm{~h}$ light:dark at Plant \& Food Research (PFR), Auckland. Potatoes infested with $>50$ greedy and latania scale insects of each life stage were placed in separate plastic containers $10 \mathrm{~cm}$ in height, tapering from $10.5 \mathrm{~cm}$ diameter at the top to $8.5 \mathrm{~cm}$ diameter at the bottom, and vented with fine wire gauze at either end (base and lid).

Onion thrips (Thrips tabaci) were reared on leeks at $23^{\circ} \mathrm{C}, 16: 8 \mathrm{~h}$ light:dark at PFR, Auckland. Sections of leeks with $>50$ adults were pinned to an apple and placed in a container as above.

Apple leafcurling midge (ALCM) (Dasineura mali) larvae were collected from infested apple leaves in Hawke's Bay in early December 2012. Leaves were placed in boxes lined with tissue paper, and larvae that moved into the tissue paper and spun cocoons were collected. Cocoons were then held at $11^{\circ} \mathrm{C}$ in complete darkness to induce diapause. Fifty diapausing larvae were placed with one apple in containers. Survival was assessed 6 days and 28 days after treatment.

Obscure mealybugs (Pseudococcus viburni) were reared on sprouting red-skinned potatoes at $20^{\circ} \mathrm{C}, 16: 8 \mathrm{~h}$ light:dark at PFR Auckland. Sections of potato with ca 30-50 mealybugs were excised with a scalpel and pinned to the calyx end of an apple and placed into a ventilated container. These apples were left for 6 days at $20^{\circ} \mathrm{C}$ for the mealybugs to move on to the apples.

There were three replicate containers for each species, except ALCM which had six to allow for destructive sampling at 6-7 days, for each treatment.

\section{Fruit}

To assess the effect of HWT on fruit quality, 'Royal Gala, 'Fuji' and 'Braeburn' apples were harvested from Hawke's Bay orchards on 11 March ('Royal Gala') and 9 April 2013 ('Fuji' and 'Braeburn') and stored at $0.5^{\circ} \mathrm{C}$ before treatment within 2 weeks of harvest. Three replicates of 30 fruit were treated.

\section{Hot water treatments}

All HWTs were implemented using custom-made water baths (95 litres). A Grundfos ${ }^{\circledR}$ circulator water pump (Model: Type UPS 32-80 B 180, Power: $240 \mathrm{~V}, 50 \mathrm{~Hz}$ ) was used to distribute the water at a rate of $3.5 \mathrm{~m}^{3} / \mathrm{h}$. Water bath heaters (Grant Instruments, Cambridge UK) heated the water to the required temperatures before entering the pump. A data logger (Squirrel, Grant Instruments, Cambridge UK) was used to record temperature at several locations within the baths.

Insects associated with apples or scale infested potatoes were exposed to hot water treatments of $49.5,51.0$ or $52.5^{\circ} \mathrm{C}$ for 1,2 or $3 \mathrm{~min}$. The insect mortality and fruit quality responses were compared to those exposed to $20^{\circ} \mathrm{C}$ water and untreated (control). Slightly different systems were used for insect and fruit treatments as follows.

For insect treatments, the containers had fine mesh (200 squares per inch, $0.085 \mathrm{~mm}$ aperture) that restricted water-flow (and thus temperature). To ensure the water was delivered at the required temperatures, containers were immersed in front of a piping system that pumped water through the top of each container and out the base. The average temperature profile for water and fruit surface inside the insect containers is shown in Figure 1.

For fruit treatments, a grid system of pipes with regular outlet holes was placed in the base of the bath and apples, in a plastic-coated mesh tray, placed above this. A second tray was placed on top of the first to hold the fruit under water. An additional heater (Eutron $2.4 \mathrm{~kW}$ ) was manually turned on ca $30 \mathrm{~s}$ before fruit were placed in the bath, then turned off 30-60 s after fruit were immersed to mitigate water temperature decrease when fruit were introduced. A typical resulting temperature profile is shown in Figure 2.

After treatment, all containers of pest infested apples and potatoes were drained and placed 
in a cool water bath $\left(\mathrm{ca} 20^{\circ} \mathrm{C}\right.$ ) for approximately 30 s. Fruit only treatments were cooled similarly for $60 \mathrm{~s}$. After cooling, the containers of insects and fruit were left to dry in an air conditioned room at $20^{\circ} \mathrm{C}$ for approximately $1 \mathrm{~h}$. Drying of fruit was aided by domestic fans.

\section{Assessments}

After treatment the insects were placed in a separate controlled temperature room set at $20^{\circ} \mathrm{C}$ until assessment. Onion thrips were assessed 1 day after treatment, obscure mealybug was assessed 2 days after treatment and greedy/latania scale and ALCM were assessed 6-7 days after treatment. Two separate groups of ALCM were treated and assessed either 6-7 days after treatment or 28 days after treatment. For onion thrips, obscure mealybug and ALCM assessed 6-7 days after treatment, insects were considered as live if movement was seen when gently prodded with forceps and dead if no movement was seen. For greedy scale the armoured cap was removed and the body visually inspected. Insects with full, turgid bodies of normal colour were assessed as live and those with flaccid, dried and/or discoloured bodies as dead. ALCM assessed 28 days after treatment was recorded as live if adult emergence had occurred or if larvae or pupae moved when prodded.

After treatment fruit was stored in cartons at $0.5^{\circ} \mathrm{C}$ for 8 weeks ('Royal Gala') or 10 weeks ('Fuji' and 'Braeburn'). After removal from cold storage, fruit was held for 7 days at $20^{\circ} \mathrm{C}$, and weight

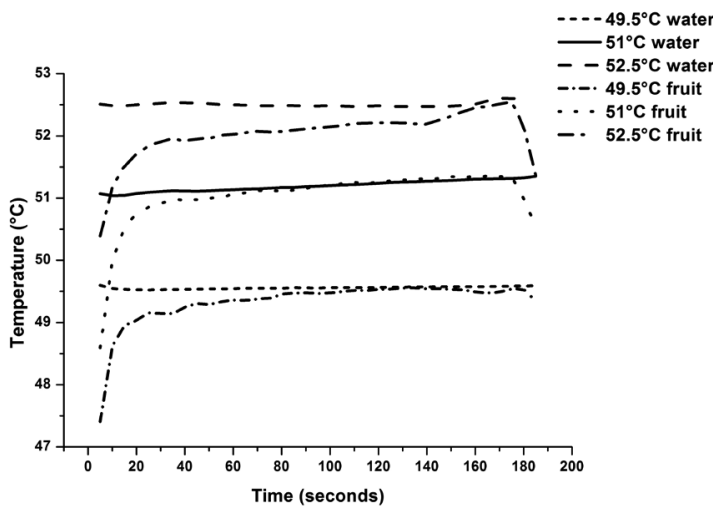

Figure 1 Temperatures recorded of water and apple surface inside pest containers during the pest efficacy trials. loss, background skin colour, internal ethylene, flesh firmness, soluble solid concentration and external disorders were measured. External disorders were scored based on approximate percentage of skin browning, i.e. $0=0 \%, 1=1-5 \%$, $2=6-25 \%, 3=26-50 \%$, $4=51-75 \%$, $5=76-100 \%$. Unacceptability was defined as any score over 2 , i.e. above $6 \%$ skin browning.

\section{Statistical analysis}

A linear mixed model was fitted to pest mortality data using Proc mixed procedure of statistical analysis system, SAS version 9.4 (SAS Inc., USA). The pest mortality was transformed by empirical logit with $100 \%$ mortality corrected. Each combination of treatment time and temperature was compared using Analysis of Variance.

Mean values of the fruit quality attributes were analysed by an analysis of variance (ANOVA) using Genstat Release v14 [(PC/Windows XP) Copyright 2005, Lawes Agricultural Trust (Rothamsted Experimental Station)]. Mean colour, incidence and unacceptability data were angular transformed $(\operatorname{ARCSIN}(\operatorname{sqrt}(\mathrm{x})))$ prior to ANOVA. Internal ethylene data (IEC) were $\log$ transformed prior to ANOVA. The untransformed data are presented in the results.

\section{RESULTS}

\section{Insects}

Of the insects tested in this study, combined scale species, latania/greedy (Figure 3), and onion

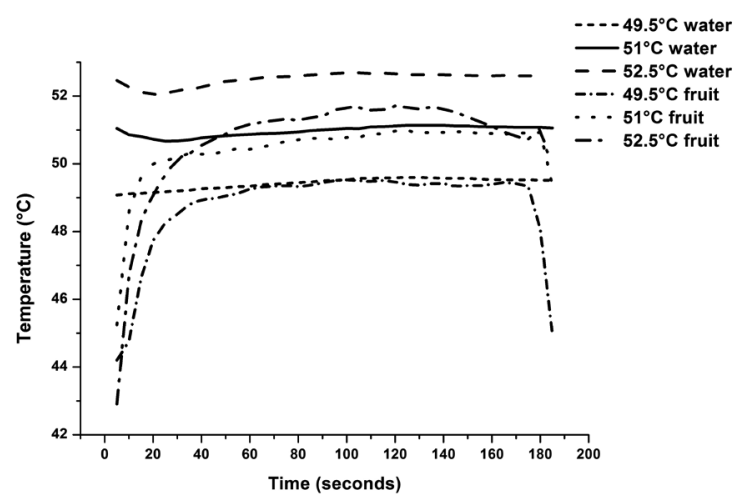

Figure 2 Temperatures recorded of water and 'Fuji' apple surface during fruit quality trials. 
thrips were the most susceptible pests to HWT. These species required either $2-3 \mathrm{~min}$ at 49.5 or $\geq$ $1 \mathrm{~min}$ at 51.0 or $52.5^{\circ} \mathrm{C}$ to achieve $>80 \%$ mortality relative to the control treatments (Figures $3 \& 4$ ). ALCM assessed 6 days after treatment showed higher mortalities than those assessed after 28 days. This could be attributed to either natural variation between two groups of insects, or to some of the ALCM being assessed as moribund-dead (no movement but still plump/juicy) after 6 days when they were actually still alive. HWT of $52.5^{\circ} \mathrm{C}$ for 1-3 minutes consistently achieved $>85 \%$ mortality of ALCM diapausing larvae when assessed either 6 or 28 days after treatment (Figure 5). Obscure mealybug was the most tolerant species tested, with mortalities achieved of $60-70 \%$ at 51.0 or $52.5^{\circ} \mathrm{C}$ for 2 or $3 \mathrm{~min}$ (Figure 6 ). There were no significant $(\mathrm{P}>0.05)$ differences between percent mortality of latania/greedy scale, onion thrips and ALCM dipped in water at $20^{\circ} \mathrm{C}$ (water control) and untreated (air control). However, there was higher mortality of obscure mealybugs dipped in $20^{\circ} \mathrm{C}$ water compared to untreated.

\section{Fruit}

No effect of HWT was found for background skin colour, internal ethylene, flesh firmness or soluble solid concentration. The only observed effect of HWT on fruit quality was external heat damage (skin browning). Differences between cultivars were observed (Figure 7) with 'Fuji' being most tolerant, 'Braeburn' moderately so and 'Royal Gala' least tolerant.

Heat damage generally increased with higher temperature and longer treatment duration (Figure 7). Little or no damage was observed at
Figure 3 Mean percentage mortality $( \pm$ SEM $)$ of combined scale insects (Hemiberlesia rapax and $H$. lataniae) exposed to hot water treatments between 49.5 and $52.5^{\circ} \mathrm{C}$ for $1-3 \mathrm{~min}$. Bars with asterisk above are significantly different from untreated air control $(\mathrm{P}<0.05)$. For each mean $\mathrm{n}=409-2533$.

Figure 4 Mean percentage mortality $( \pm$ SEM) of onion thrips (Thrips tabaci) exposed to hot water treatments between 49.5 and $52.5^{\circ} \mathrm{C}$ for $1-3 \mathrm{~min}$. Bars with asterisk above are significantly different from untreated air control $(\mathrm{P}<0.05)$. For each mean $\mathrm{n}=33-164$.
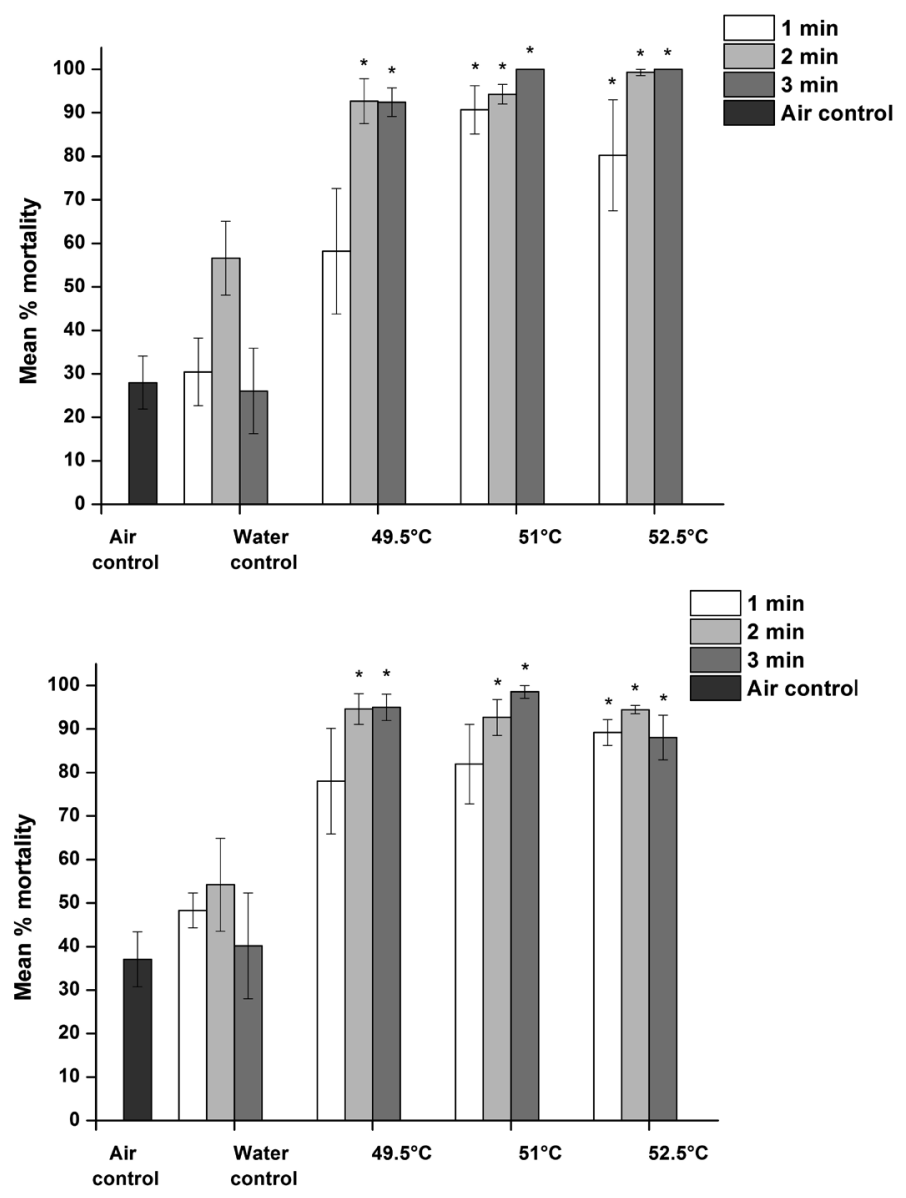
Figure 5 Mean percentage mortality $( \pm$ SEM $)$ of apple leafcurling midge (Dasineura mali) at (a) 6 or (b) 28 days after exposure to hot water treatments between 49.5 and $52.5^{\circ} \mathrm{C}$ for $1-3 \mathrm{~min}$. Bars with asterisk above are significantly different from untreated air control $(\mathrm{P}<0.05)$. For each mean $\mathrm{n}=129-515$.
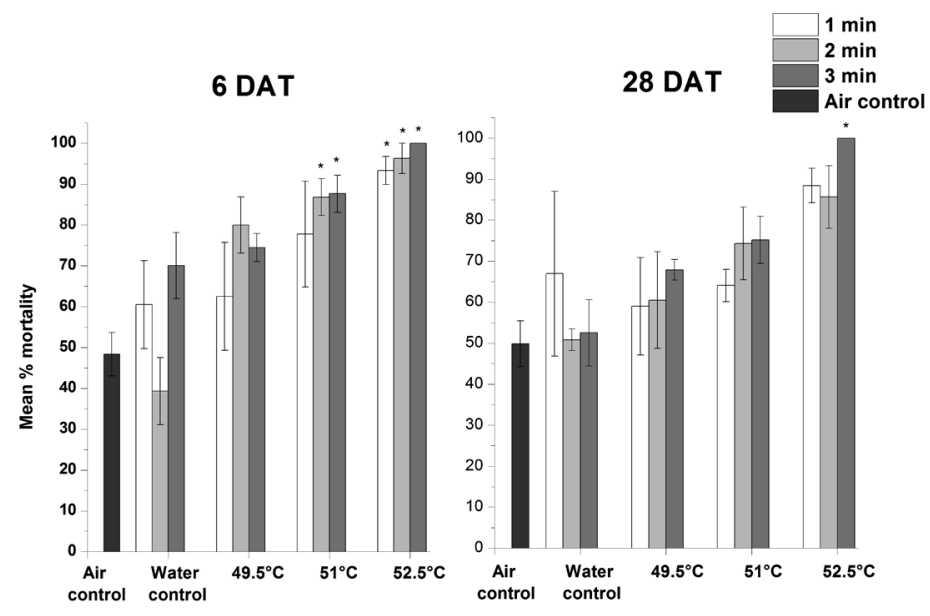

Figure 6 Mean percentage mortality $( \pm$ SEM) of obscure mealybugs (Pseudococcus viburni) exposed to hot water treatments between 49.5 and $52.5^{\circ} \mathrm{C}$ for $1-3 \mathrm{~min}$. Bars with asterisk above are significantly different from both water and air control $(\mathrm{P}<0.05)$. For each mean $\mathrm{n}=321-1702$.

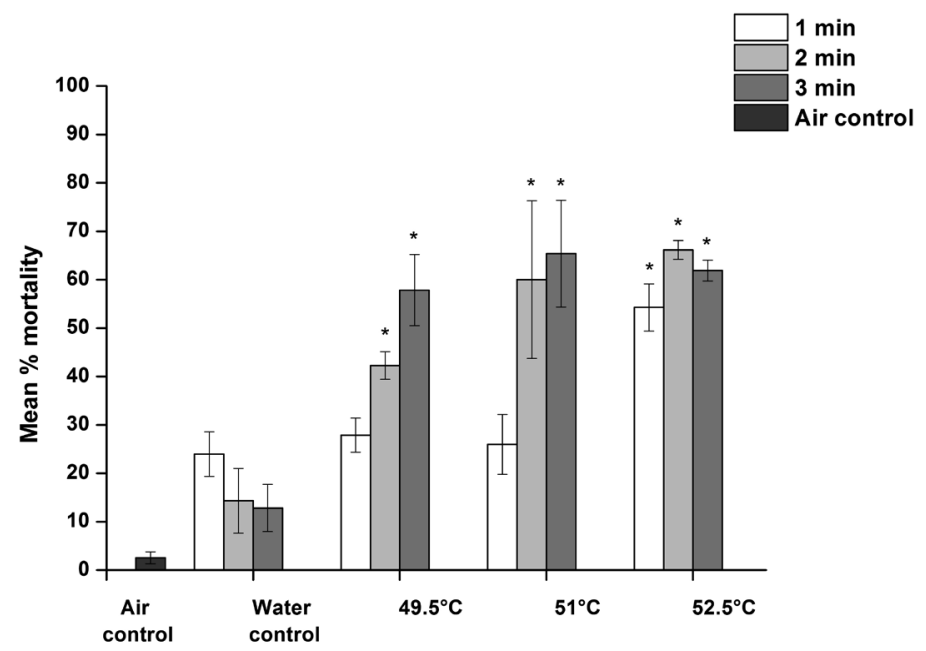

$49.5^{\circ} \mathrm{C}$ for $1 \mathrm{~min}$, and few apples $(<10 \%)$ were damaged at this temperature at $3 \mathrm{~min}$. No damage was observed to 'Fuji' and 'Braeburn' at $51.0^{\circ} \mathrm{C}$ for any treatment time but 'Royal Gala' was affected by the 3 min treatment with $60 \%$ fruit damaged and $20 \%$ unacceptably so (Figure 7 ). At $52.5^{\circ} \mathrm{C}$ no damage was observed to any cultivar following a 1-min HWT but at longer durations there was damage, and this increased with time to ca $100 \%$ unacceptability for 'Royal Gala' and 'Braeburn', and $60 \%$ for 'Fuji' (Figure 7).

\section{DISCUSSION}

This research has shown the potential of shortduration HWTs to achieve high kill rates of a range of insects, while not damaging fruit, although there were differences in effectiveness between pests, with thrips and scale being most susceptible and mealybugs most tolerant of HWT. Most previous disinfestation and fruit quality research using HWT used lower temperatures $\left(\mathrm{ca} 45^{\circ} \mathrm{C}\right.$ ) and treatment times of up to $30 \mathrm{~min}$ (Jamieson et al. 2009). When shorter HWT treatments at $49-50^{\circ} \mathrm{C}$ have been investigated, thrips were shown to be most susceptible (McLaren et al. 1997; McLaren \& Fraser 1998), followed by tydeid mites (Waddell et al. 1993) and native leafrollers (Jones 1993; Waddell \& Alderson 1998), compared to more tolerant species such as lightbrown apple moth, mealybugs and two-spotted mites (Waddell et al. 1993; Lester et al. 1995). 

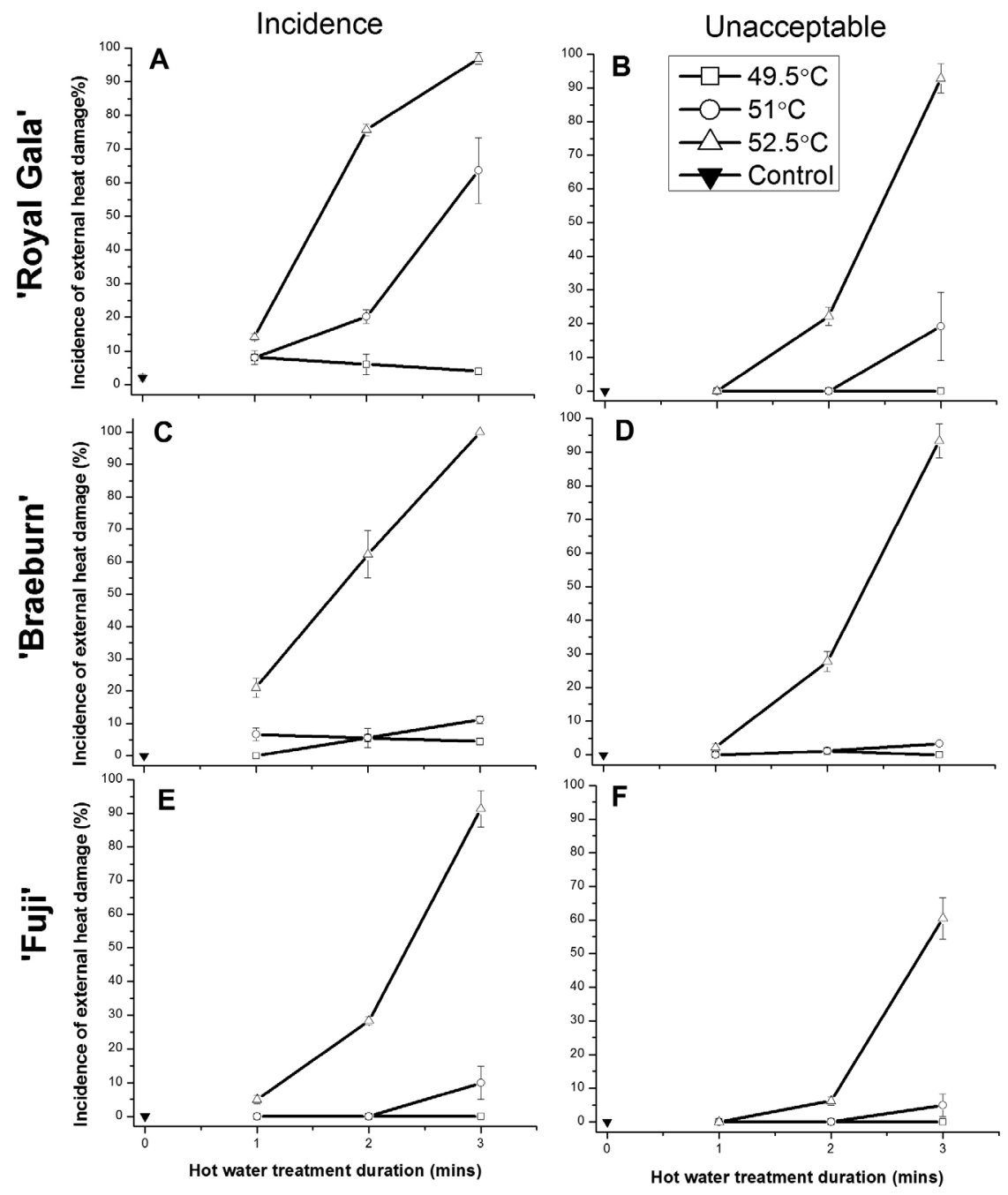

Figure 7 Mean incidence (any heat damage as indicated by skin browning) and unacceptable damage ( $>6 \%$ of skin surface) on 'Royal Gala, 'Braeburn' and 'Fuji' apples following hot water treatments at $49.5^{\circ} \mathrm{C}, 51.0^{\circ} \mathrm{C}$ and $52.5^{\circ} \mathrm{C}$ for 1,2 or $3 \mathrm{~min}$. Control fruit were held at $20^{\circ} \mathrm{C}$ in air. Damage was rated after storage for 8 weeks ('Royal Gala') or 10 weeks ('Braeburn' and 'Fuji') at $0.5^{\circ} \mathrm{C}$ and subsequently held for 7 days at $20^{\circ} \mathrm{C}$. Treatments were carried out in triplicate and standard error of the mean is presented (vertical bars).

In this study ALCM appeared to be quite sensitive to HWTs, with over $85 \%$ mortality at $52.5^{\circ} \mathrm{C}$ for $\geq 1 \mathrm{~min}$. This is a significant result given that this pest can be very tolerant of other disinfestation treatments such as ethyl formate fumigation (Jamieson et al. 2014).

A HWT of $51.0^{\circ} \mathrm{C}$ for 2 min caused no damage to 'Royal Gala,' 'Fuji' and 'Braeburn' apples, while having the potential to control $94 \%$ greedy/latania scale, $93 \%$ onion thrips, $88 \%$ diapausing ALCM larvae and $65 \%$ obscure mealybugs. The lower rate of control for mealybugs is not concerning as these are highly susceptible to removal from fruit by high pressure washing (Woolf et al. 2014), fumigation with ethyl formate (Jamieson et al. 2014) and cold storage (Jamieson et al. 2010). 
Moving apples by water is an integral part of apple pack-house processing to which HWT could be added as a part of the continuous flow system. There is potential that a systems approach using multiple in-line pest mitigation treatments, such as application of high pressure washing, HWT and/or UV-C, followed by ethyl formate fumigation and/or cold storage could lead to acceptable and consistent disinfestation outcomes.

\section{ACKNOWLEDGEMENTS}

Thanks to Stella McLeod of Mr Apple, and Bridie Carr and Matt Punter of PFR for assistance with sourcing fruit; Frances MacDonald, Vicky Davis, Miae Cho, Dominic Hartnett and Nidhi Sharma for technical assistance with pest and apple treatments and assessments; Lindy Guo for statistical analysis. This research was funded by Pipfruit New Zealand.

\section{REFERENCES}

Fallik E 2004. Prestorage hot water treatments (immersion, rinsing and brushing). Postharvest Biology and Technology 32: 125134.

Ferguson IB, Ben-Yehoshua S, Mitcham EJ, McDonald RE, Lurie S 2000. Postharvest heat treatments: introduction and workshop summary. Postharvest Biology and Technology 21: 1-6.

Heather NW, Hallman GJ 2008. Phytosanitary heat treatments. Chapter 8. In: Pest management and phytosanitary trade barriers. CABI (ISBN 1845933443). Pp. 111-131.

Jamieson LE, Connolly PG, Page-Weir NEM 2010. A quick reference guide for pest mortality during coolstorage. Report to Zespri Group Limited, Plant \& Food Research Report No. 38214, Plant \& Food Research, Auckland, New Zealand. 49 pp.

Jamieson LE, Griffin M, Page-Weir NEM, Chhagan A, Redpath S, Connolly PG 2014. Developing ethyl formate treatment for disinfesting pipfruit. New Zealand Plant Protection 67: 96-102.
Jamieson LE, Meier X, Page BBC, Zulhendri F, PageWeir NEM, Brash D, McDonald RM, Stanley J, Woolf $A B$ 2009. A review of postharvest disinfestation technologies for selected fruits and vegetables. Report to Horticulture New Zealand, Plant \& Food Research Report No. 3100, Plant \& Food Research, Auckland, New Zealand. $167 \mathrm{pp}$.

Jones V, Waddell, BC, Maindonald, JH 1993. Heat Treatment of New Zealand Apples Leafroller Waterbath Trials. Report to New Zealand Apple and Pear Marketing Board and the Foundation for Research Science and Technology, HortResearch Report No. 93/273, HortResearch, Palmerston North, New Zealand. 22 pp.

Lester PJ, Dentener PR, Petry RJ, Alexander SM 1995. Hot-water immersion for disinfestation of lightbrown apple moth (Epiphyas postvittana) and longtailed mealy bug (Pseudococcus longispinus) on persimmons. Postharvest Biology and Technology 6: 349-356.

Lurie S, Fallik, E, Klein, JD, Kozar, F, Kovacs, K 1998. Postharvest heat treatment of apples to control San Jose scale (Quadraspidiotus perniciosus Comstock) and blue mold (Penicillium expansum Link) and maintain fruit firmness. Journal of the American Society for Horticultural Science 123: 110-114.

Mangan R, Hallman G 1997. Temperature treatments for quarantine security: New approaches for fresh commodities. In: Hallman G, Denlinger D ed. Thermal sensitivity in insects and application in integrated pest management. Westview Press, Boulder, Colorado, USA. 311 pp.

Maxin P, Weber RWS, Pedersen HL, Williams M 2012a. Hot-water dipping of apples to control Penicillium expansum, Neonectria galligena and Botrytis cinerea: effects of temperature on spore germination and fruit rots. European Journal of Horticultural Science 77: 1-9.

Maxin P, Weber RWS, Pedersen HL, Williams M 2012b. Control of a wide range of storage rots in naturally infected apples by hot-water dipping and rinsing. Postharvest Biology and Technology 70: 25-31. 
McLaren GF, Fraser JA 1998. Upper thermotolerance of New Zealand flower thrips Thrips obscuratus (Crawford). Proceedings of the 51st New Zealand Plant Protection Conference: 204-210.

McLaren GF, Fraser JA, McDonald RM 1997. The feasibility of hot water disinfestation of summerfruit. Proceedings of the 50th New Zealand Plant Protection Conference: 425-430.

Spooner KJ, Lay-Yee M 1994. Response of Granny Smith apples to hot water treatment and $38^{\circ} \mathrm{C}$ pretreatments. Report to ENZA New Zealand (International), HortResearch Report No. 94/318, HortResearch, Palmerston North, New Zealand. 56 pp.

Spooner KJ, Lay-Yee M 1995. Response of Braeburn apples to hot water treatments for insect control. Report to ENZA New Zealand (International), HortResearch Report No. 95/273, HortResearch, Palmerston North, New Zealand. 72 pp.
Tang J, Mitcham E, Wang S, Lurie S ed. 2007. Heat treatments for postharvest pest control. $\mathrm{CAB}$ International, Wallingford, Oxford, UK. 349 pp.

Teruya R, Takushi T, Hirose N, Makishi Y, Ooshiro Y 2012. Short hot water treatment for control of anthracnose in mango. Horticultural Research (Japan) 11: 265-271.

Waddell BC, Alderson SL 1998. Heat Treatment of New Zealand Apples - Leafroller Water Treatments. Report to ENZA New Zealand (International), HortResearch Report No. 98/26, HortResearch, Palmerston North, New Zealand. 73 pp.

Waddell BC, Jones VM, Birtles DB 1993. Comparative mortality responses to two species of mites following heat treatment. Proceedings of the 46th New Zealand Plant Protection Conference: 1-5.

Woolf A, McDonald R, Rogers D, Olsson, S, Redpath S, ODonoghue E, Cate L, Griffin M, Page-Weir N, Chhagan A, White A, Walker J, Jamieson L 2014 Advances in application of high pressure washing to enhance market access. Acta Horticulturae: in press. 